\title{
EKSPERYMENTALNE BADANIA WPEYWU UTRATY KOŃCÓWKI SKRZYDŁA SAMOLOTU TU-154M NA JEGO RÓWNOWAGĘ POPRZECZNĄ
}

\author{
ANDRZEJ KRZYSIAK \\ Sieć Badawcza Lukasiewicz - Instytut Lotnictwa, Warszawa \\ e-mail: andkrzys@ilot.edu.pl
}

Aleksander Olejnik, Łukasz Kiszkowiak

Wojskowa Akademia Techniczna, Warszawa

e-mail: a;eksander.olejnik@wat.edu.pl, lukasz.kiszkowiak@wat.edu.pl

\begin{abstract}
W pracy przedstawiono wyniki eksperymentalnych badań modelu samolotu Tu-154M w skali 1:14. Model wytworzono w większości w technologii kompozytowej z metalowymi elementami mocowania i mniejszymi elementami drukowanymi w technologii 3D. Model samolotu Tu154M został zaprojektowany i wykonany przez Wojskową Akademię Techniczną w oparciu o dokładną geometrię samolotu, uzyskaną przez skanowanie obiektu rzeczywistej wielkości. Badania obejmowały pomiary podstawowych charakterystyk aerodynamicznych modelu samolotu w skali 1:14 w szeregu konfiguracjach, w tym w konfiguracji do lacdowania (sloty i podwozie wysunięte, klapy wychylone na $36^{\circ}$ ) ze skrzydłem w pełnym obrysie, oraz w tej samej konfiguracji, lecz z obciętą końcówka lewego skrzydła (w przybliżeniu w 1/3 jego rozpiętości). Wykonane badania pozwoliły na określenie wpływu utraty końcówki skrzydła samolotu Tu-154M na jego równowagę poprzeczną. Badania modelu samolotu Tu-154M wykonane zostały w tunelu małych prędkości T-3 Instytutu Lotnictwa (średnica przestrzeni pomiarowej $5 \mathrm{~m}$ ) dla prędkości przepływu niezakłóconego $V=75 \mathrm{~m} / \mathrm{s}$, co odpowiadało liczbie Reynoldsa (odniesionej do średniej cięciwy aerodynamicznej modelu), Re =1,67 $10^{6}$. Pomiary charakterystyk aerodynamicznym modelu samolotu Tu-154M zrealizowane zostały zarówno przy zmiennym kącie natarcia, tj. dla $-8^{\circ} \leqslant \alpha \leqslant 22^{\circ}$ przy kącie ślizgu $\beta=0^{\circ}$, jak i przy zmiennym kącie ślizgu, tj. dla $10^{\circ} \leqslant \beta \leqslant 16^{\circ}$ przy kątach natarcia $\alpha=0^{\circ}, 10^{\circ}, 12,5^{\circ}$. Omawiane w pracy badania wykonano na zamówienie Podkomisji do Ponownego Zbadania Wypadku Lotniczego, działajaccej przy Ministerstwie Obrony Narodowej.
\end{abstract}

\section{Wykaz oznaczeń}

$b$ - rozpiętość skrzydeł modelu $[\mathrm{m}]$

$C z, C x$ - odpowiednio współczynnik siły nośnej i oporu

$C m x, C m y, C m z$ - odpowiednio współczynnik momentu przechylającego, pochylającego i odchylającego

$L$ - długość modelu [m]

M - liczba Macha przepływu niezakłóconego

Re - liczba Reynoldsa

$S C A$ - średnia cięciwa aerodynamiczna $[\mathrm{m}]$

$V$ - prędkość przepływu niezakłóconego $[\mathrm{m} / \mathrm{s}]$

$\alpha, \beta$-odpowiednio kąt natarcia i ślizgu [deg]

\section{Wprowadzenie}

Historia lotnictwa zna wiele wypadków lotniczych, kiedy w wyniku zderzenia z innymi obiektami (latającymi lub naziemnymi) samoloty zostały poważnie uszkodzone lub też utracono jego 
część. W szczególności utrata części powierzchni sterowych lub powierzchni nośnych była bardzo niebezpieczna i często prowadziła do katastrofy. Wynikało to najczęściej z braku możliwości sterowania lotem samolotu lub braku umiejętności odpowiedniej reakcji załogi samolotu w takiej sytuacji.

Zdarzały się również inne wypadki, gdy pomimo utraty lub poważnego uszkodzenia części samolotu, w tym powierzchni nośnych i powierzchni sterowych, załodze samolotu udało się bezpiecznie wylądować. Wielokrotnie opisywano wypadek, który miał miejsce w 1965 roku z udziałem samolotu Boeing 707-321B, a dotyczył utraty znacznej części skrzydła (około 1/3) oraz lotki zewnętrznej w skutek wybuchu w jednym z silników [1]. Mimo znacznego uszkodzenia skrzydła załodze udało się bezpiecznie wylądować, co uratowało życie ponad 150 osobom biorącym udział $\mathrm{w}$ tym locie. Inne znane przypadki pomyślnego zakończenia lotu, pomimo istotnego uszkodzenia samolotu (w tych przypadkach chodziło o utratę jednego ze skrzydeł), dotyczyły samolotów wojskowych F-15D Eagle [2], [3] oraz F-16C [4].

Określenie charakterystyk aerodynamicznych samolotu z uszkodzonymi lub też utraconymi częściami tego samolotu stały się przedmiotem badań naukowych. Takie eksperymentalne badania prowadzone były między innymi przez Shah G.H. w roku 2008 i 2012 [5], [6] w tunelu aerodynamicznym NASA. W tym przypadku przedmiotem badań był model samolotu transportowego.

Opisane w artykule badania nawiązują do katastrofy polskiego rządowego samolotu Tupolew Tu-154M w pobliżu Smoleńska w Rosji w roku 2010. Powołane tuż po katastrofie komisje specjalne (polska i rosyjska), których celem było zbadanie przyczyn tego wypadku, uznały utratę końcówki lewego skrzydła za bezpośrednią przyczyną katastrofy.

Powołana w roku 2016 Podkomisja do ponownego zbadania katastrofy smoleńskiej zleciła Instytutowi Lotnictwa, w ramach prowadzonego przez Wojskową Akademie Techniczną projektu badawczego „Opracowanie technologii odtwarzania geometrii zewnętrznej i struktury wewnętrznej dużych samolotów na potrzeby budowy modeli numerycznych" pod kryptonimem „LARE" (ang. Large Aircraft Reverse Engineering), przeprowadzenie eksperymentalnych badań podstawowych charakterystyk aerodynamicznych modeli samolotu Tu-154M w szeregu konfiguracjach.

W artykule przedstawiono wybrane wyniki badań modelu samolotu Tu-154M w skali 1:14 w tunelu aerodynamicznym T-3. W pracy przedstawiono wpływ utraty końcówki skrzydła na podstawowe charakterystyki aerodynamiczne samolotu Tu-154M, w tym na równowage boczną samolotu. Badania wykonano przy prędkości przepływu niezakłóconego $V=75 \mathrm{~m} / \mathrm{s}$, co odpowiada liczbie Reynoldsa (odniesionej do $S C A$ modelu) $\operatorname{Re}=1,67 \cdot 10^{6}$.

\section{Tunel aerodynamiczny małych prędkości T-3}

Tunel aerodynamiczny T-3 o średnicy $5 \mathrm{~m}$ jest tunelem atmosferycznym o obiegu zamkniętym $\mathrm{z}$ otwartac przestrzenią pomiarową [7]. Wymiary przestrzeni pomiarowej wynoszą: średnica $5 \mathrm{~m}$, długość $6,5 \mathrm{~m}$. W przestrzeni pomiarowej można osiągnąć maksymalną prędkość ok. $90 \mathrm{~m} / \mathrm{s}$. Silnik o mocy ok. 5,6 MW napędza ośmiołopatowy wentylator. Maksymalne obroty wentylatora wynoszą $400 \mathrm{obr} / \mathrm{min}$. Regulacja prędkości odbywa się w sposób ciągły od ok. $3,2 \mathrm{~m} / \mathrm{s}$ do $90 \mathrm{~m} / \mathrm{s}$. Schemat tunelu T-3 przedstawiono na rys. 1

\section{Technika badań}

Badania wagowe modelu samolotu Tu-154M w skali 1:14 zostały przeprowadzone w tunelu T-3 na tensometrycznej wadze aerodynamicznej AEROTECH 0460, umożliwiającej pomiary pięciu składowych sił i momentów aerodynamicznych działających na model, tj.: $P x, P z, M x$, $M y, M z$. 


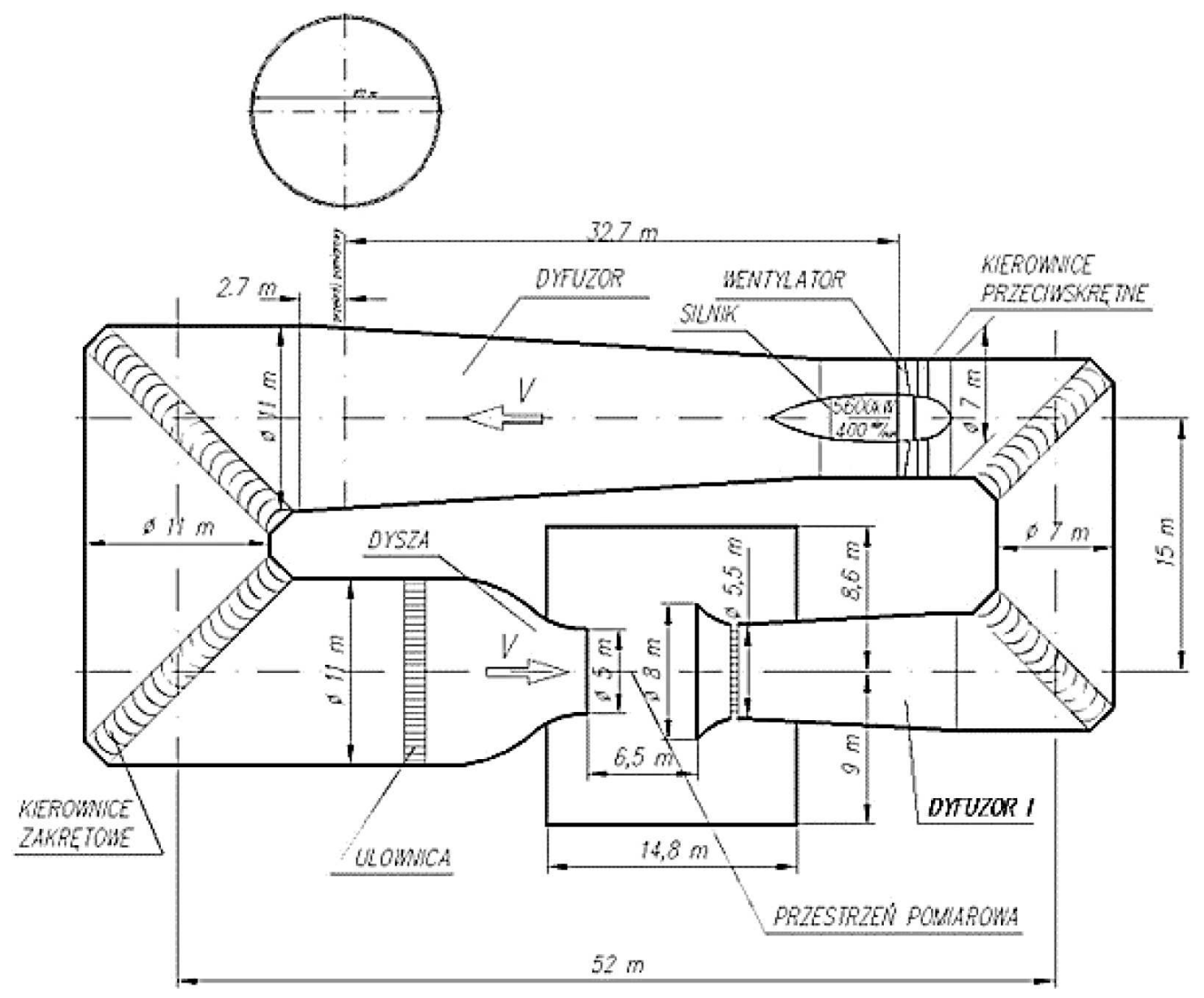

Rys. 1. Schemat tunelu aerodynamicznego T-3

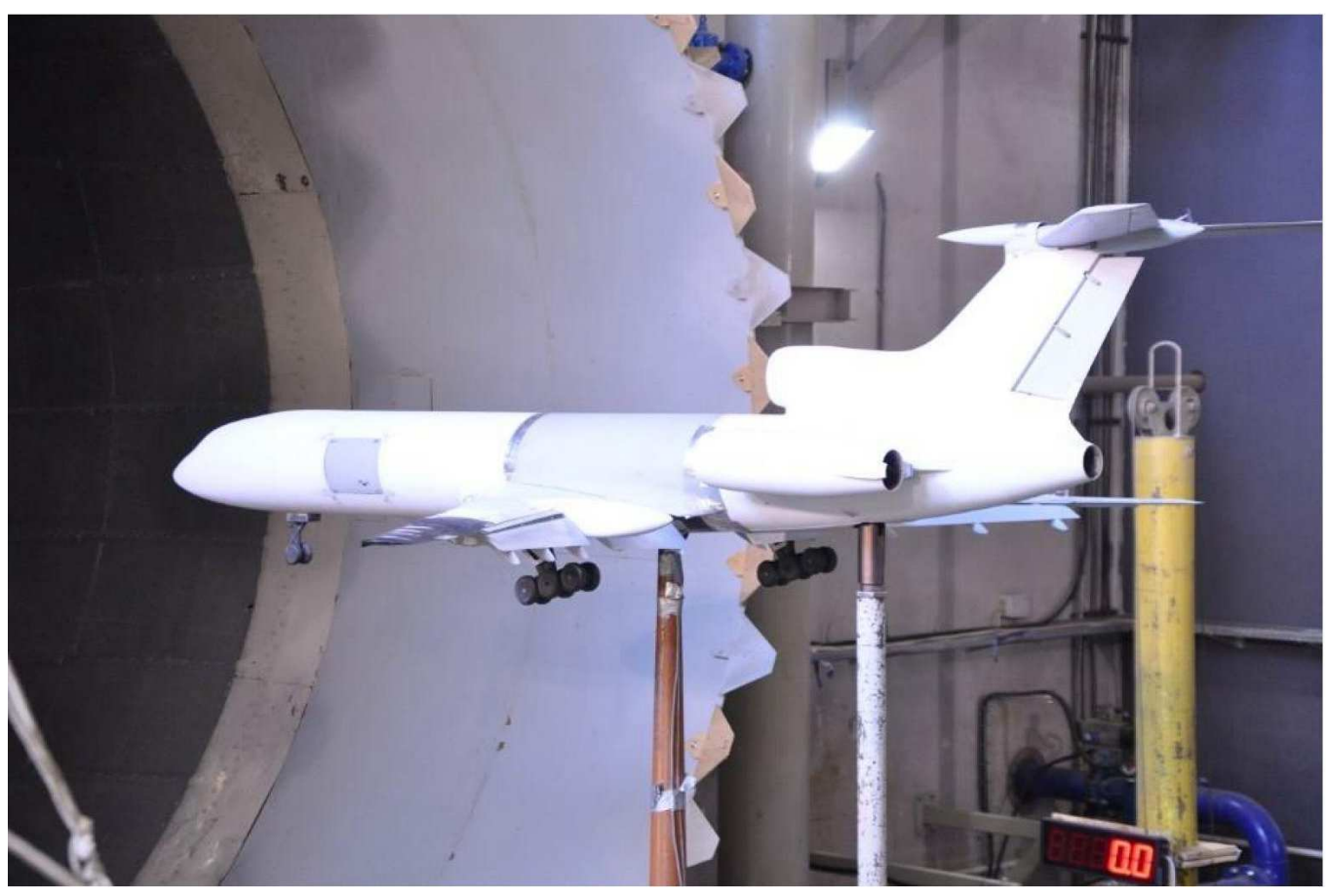

Rys. 2. Zamocowanie modelu samolotu Tu-154 M w tunelu T-3 
Model samolotu Tu-154M w skali 1:14 zamocowano w przestrzeni pomiarowej tunelu T-3 na dwóch podporach: przedniej oraz tylnej. Model zamontowany na wadze w tunelu przedstawiono na rys. 2. Mechanizm napędu pozwolił na wykonanie badań w zakresie kątów natarcia $\alpha=-8^{\circ} \div 22^{\circ}$ oraz kątów ślizgu $\beta=-10^{\circ} \div 16^{\circ}$.

Charakterystyki aerodynamiczne przedstawione $\mathrm{w}$ niniejszym opracowaniu odniesione są do układu współrzędnych $X O Y Z$, związanego z kierunkiem przepływu niezakłóconego wzdłuż osi $O X$, rys. 3. Na rysunku 3 przedstawiono ponadto układ współrzędnych związany z modelem $X_{0} O Y_{0} Z_{0}$, gdzie oś kadłuba pokrywa się z osią $O X_{0}$, oraz kąty obrotu pomiędzy tymi układami, tj. kąt natarcia $\alpha$ oraz kat ślizgu $\beta$. Osie $O X_{0}$ oraz $O Z_{0}$ leżą w płaszczyźnie symetrii samolotu. Położenie środka układu współrzędnych $O$ zdefiniowano następująco:

- oś symetrii kadłuba,

- 25\% SCA, tj. 1,66 m od noska modelu.

Dane geometryczne modelu przyjęte do obliczeń współczynników aerodynamicznych: $S=0,918 \mathrm{~m}^{2}, S C A=0,377 \mathrm{~m}$ - długość odniesienia dla momentu pochylającego $M y$, $b=2,682 \mathrm{~m}$ - długość odniesienia dla momentu przechylającego $M x$ i odchylającego $M z$.

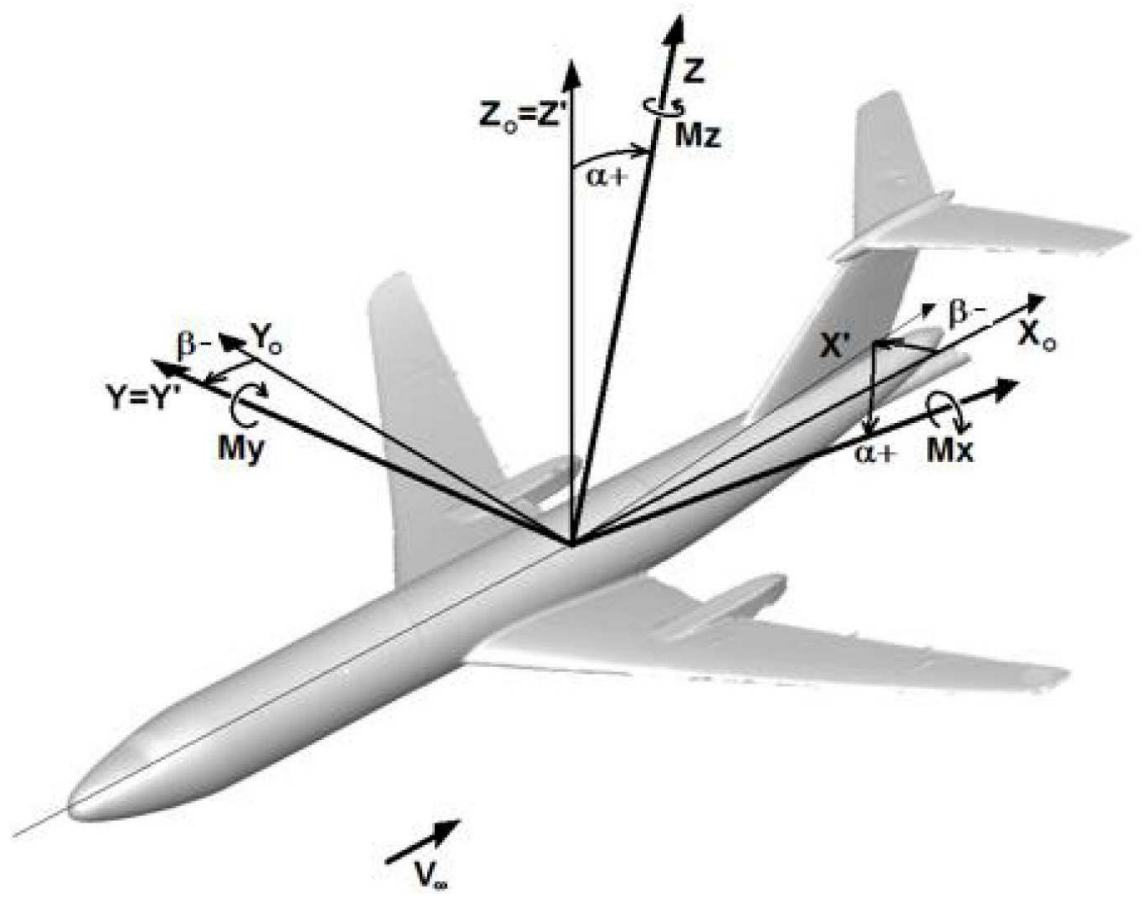

Rys. 3. Przyjęty układ współrzędnych

Badania wagowe modelu samolotu Tu-154M w skali 1:14, w zasadniczej swej części, przeprowadzono dla prędkości $V=75 \mathrm{~m} / \mathrm{s}$, co odpowiada liczbie Reynoldsa (odniesionej do średniej cięciwy aerodynamicznej) $\operatorname{Re}=1,67 \cdot 10^{6}$.

\section{Badany model}

Prezentowane $\mathrm{w}$ pracy badania przeprowadzone zostały przy użyciu modelu samolotu Tu-154M w skali 1:14 o rozpiętości skrzydeł $b=2,682 \mathrm{~m}$ i długości modelu $L=3,42 \mathrm{~m}$. Model wytworzono w większości w technologii kompozytowej z metalowymi elementami mocowania i mniejszymi elementami drukowanymi w technologii 3D. Model samolotu Tu-154M został zaprojektowany i wykonany przez Wojskową Akademię Techniczną w oparciu o dokładną geometrię 
samolotu, uzyskaną przez skanowanie obiektu rzeczywistej wielkości [8]. Model odwzorowywał wszystkie powierzchnie sterowe wraz ze szczelinami pomiędzy tymi powierzchniami a główną częścią skrzydła. Na rys. 4 przedstawiono model samolotu Tu-154M w skali 1:14 w tunelu T-3 Instytutu Lotnictwa. Odrzucana część skrzydła (co było przedmiotem osobnych badań) pomalowana jest w kolorze jasno czarnym.

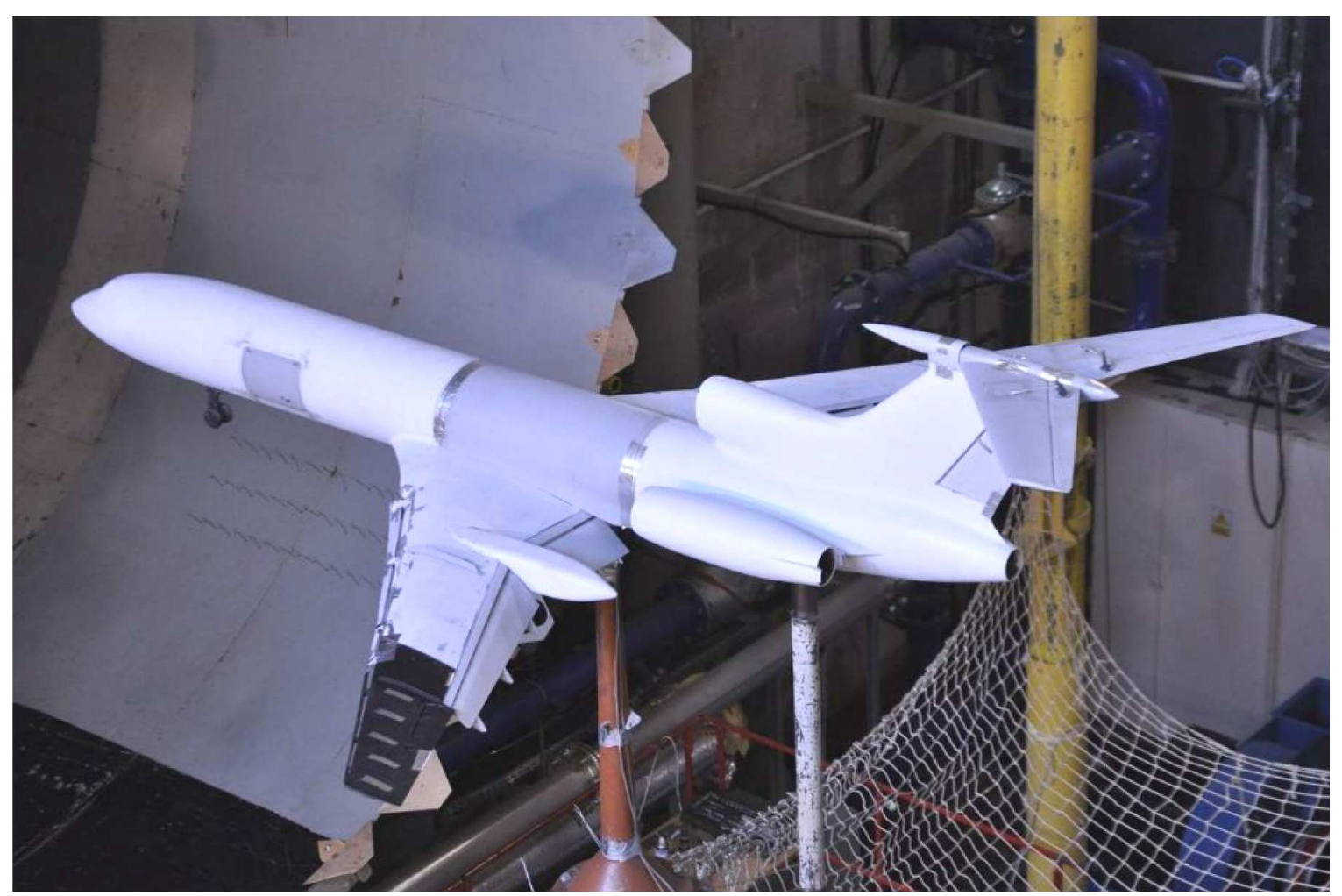

Rys. 4. Model samolotu Tu-154M w skali 1:14 w tunelu T-3 Instytutu Lotnictwa

Badane konfiguracje modelu samolotu Tu-154M w skali 1:14 zostały oznaczone w następujący sposób:

$$
\delta_{F} / \delta_{S Z}-\delta_{S S ́}-\delta_{S W} / \delta_{L} / \delta_{R} / \delta_{h} / \delta_{V} / \delta_{H T}+S+P
$$

gdzie:

$\delta_{F}-$ kąt wychylenia klap [deg],

$\delta_{S Z}$ - kąt wychylenia zewnętrznego hamulca aerodynamicznego na prawym skrzydle [deg],

$\delta_{S S ́}-$ kąt wychylenia środkowego hamulca aerodynamicznego na obu skrzydłach [deg],

$\delta_{S W}$ - kąt wychylenia wewnętrznego hamulca aerodynamicznego na obu skrzydłach [deg],

$\delta_{L R}$ - kąt wychylenia lotek [deg], wartość dodatnia - wychylenie do dołu,

$\delta_{h}$ - kąt wychylenia steru wysokości [deg], wartość dodatnia - wychylenie do dołu,

$\delta_{V}$ - kąt wychylenia steru kierunku [deg], wartość dodatnia - wychylenie w kierunku lewego skrzydła,

$\delta_{H T}$ - kąt zaklinowania statecznika poziomego [deg], wartość dodatnia zwiększa jego kąt natarcia względem przepływu,

$S$ - sloty wysunięte,

$P$ - podwozie wysunięte'

Model samolotu Tu-154M w skali 1:14 w konfiguracji do lądowania badany był tunelu T-3 w dwóch wariantach, tj. ze skrzydłem całym oraz z obciętą końcówką lewego skrzydła. Położenie linii obcięcia końcówki lewego skrzydła samolotu przestawiono na rys. 5. 


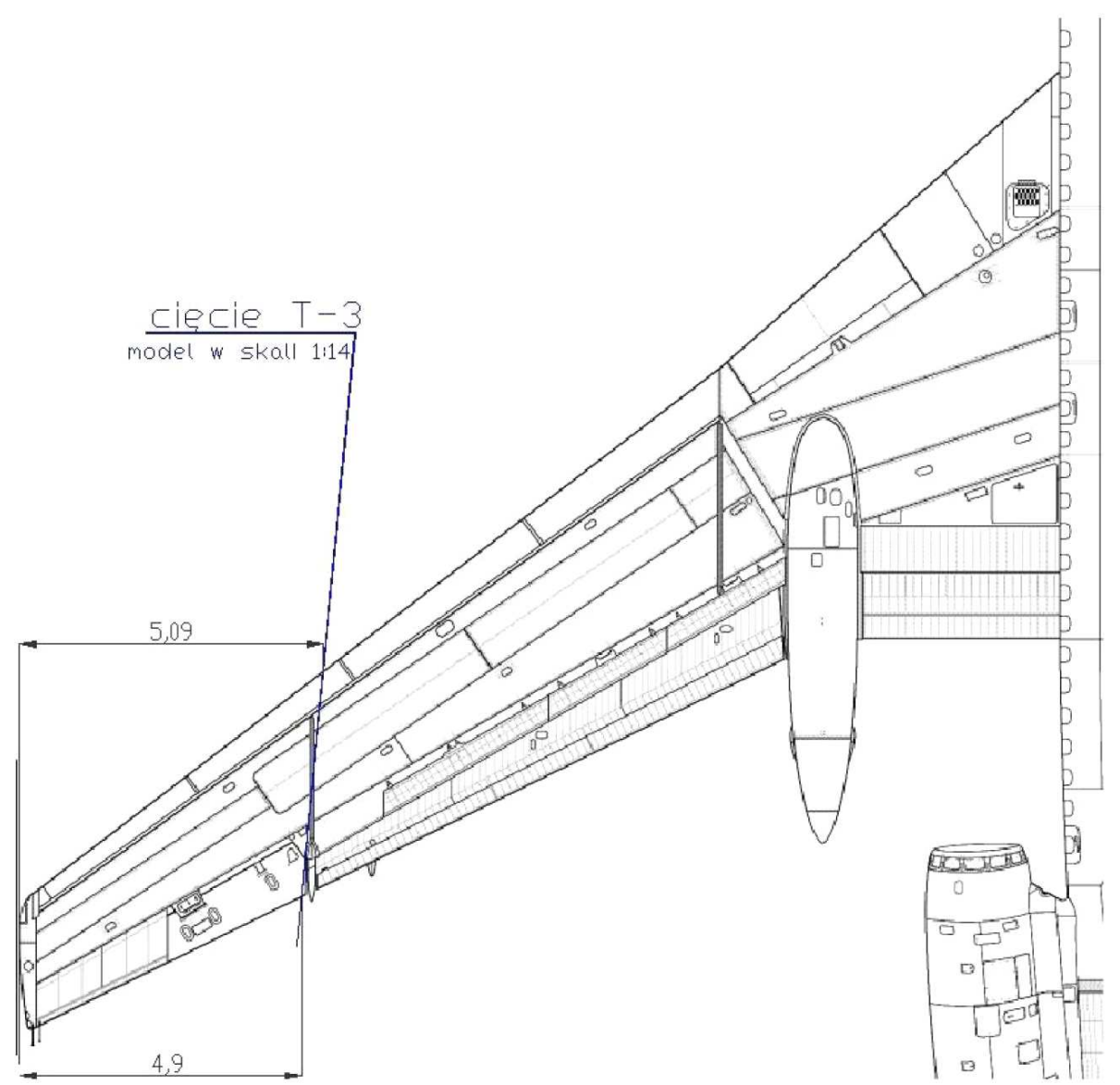

Rys. 5. Położenie linii obcięcia końcówki lewego skrzydła samolotu Tu-154M

\section{Wyniki badań}

Na rys. 6 i 7 porównano uzyskane w tunelu T-3 zależności współczynnika siły nośnej w funkcji kąta natarcia z wynikami badań: z tunelu T-1 [9], z obliczeniami numerycznymi oraz z rosyjskimi badaniami samolotu Tu-154M w locie [10] dla konfiguracji przelotowej oraz konfiguracji do lądowania.

Dla konfiguracji przelotowej samolotu w całym zakresie podkrytycznych kątów natarcia uzyskano niezłą zgodność wszystkich porównywanych wyników badań. Natomiast w przypadku konfiguracji do lądowania (klapy, sloty i podwozie wysunięte) zgodność uzyskanych wyników badań z tuneli aerodynamicznych z wynikami badań w locie jest nieco gorsza. Jak można przypuszczać, wynika to faktu, że w przypadku eksperymentalnych badań skalowanych modeli brak jest możliwości prawidłowego odwzorowania przepływu w szczelinie pomiędzy slotem a skrzydłem oraz w szczelinach wysuniętej klapy.

Na rys. $8 \div 11$ przedstawiono wpływ utraty końcówki skrzydła na wybrane współczynniki aerodynamiczne modelu samolotu Tu-154M w konfiguracji do lądowania (sloty i podwozie wysunięte, klapy wychylone na kąt $36^{\circ}$ ).

Na rys. 12 i 13 przedstawiono wpływ wychylenia prawej lotki oraz prawego zewnętrznego spoilera, a także kąta ślizgu na współczynnik momentu przechylającego.

Jak można przypuszczać, niezerowa wartość współczynnika momentu przechylającego dla konfiguracji modelu ze skrzydłem całym (rys. 10 i 12) wynika z braku symetrii modelu względem jego teoretycznej płaszczyzny symetrii. 


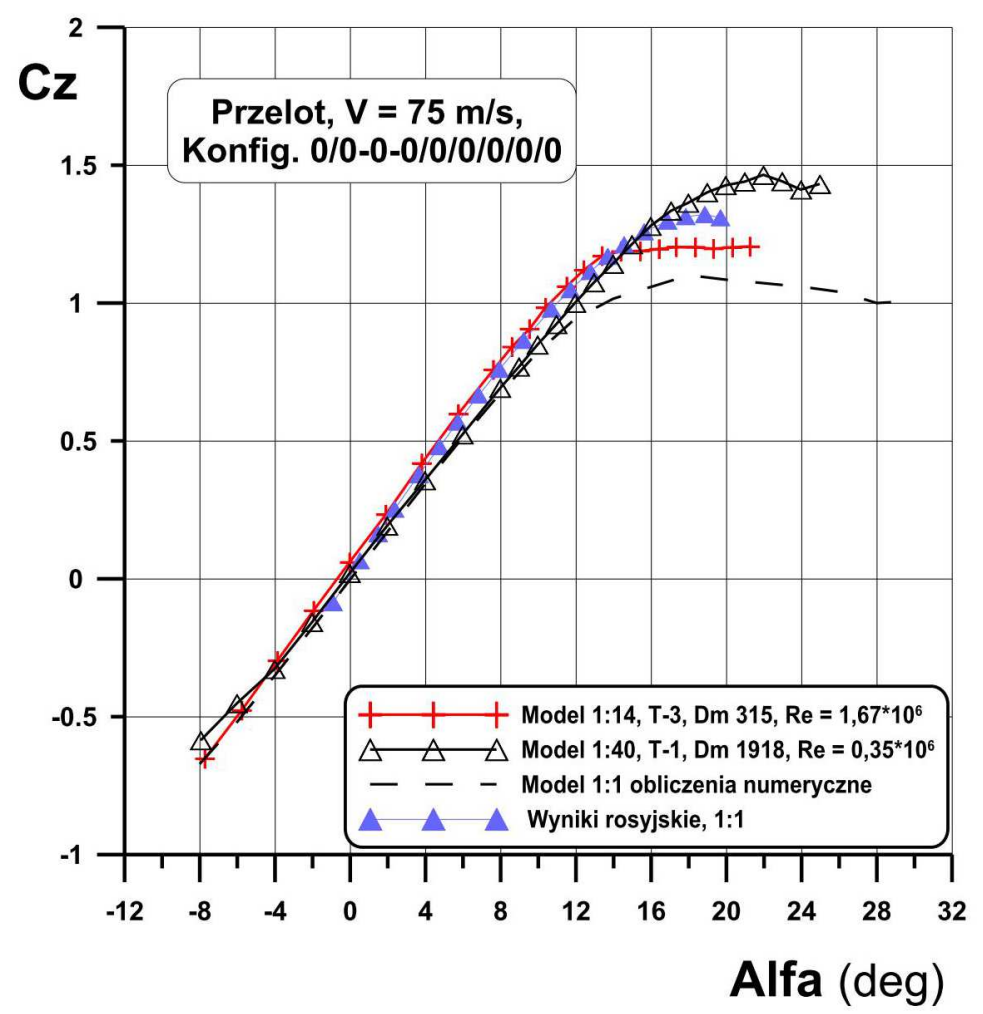

Rys. 6. Porównanie zależności $C z=(\alpha)$ uzyskanych w tunelach T-3 i T-1 oraz z wynikami obliczeń numerycznych i rosyjskich badań w locie dla konfiguracji przelotowej s-tu

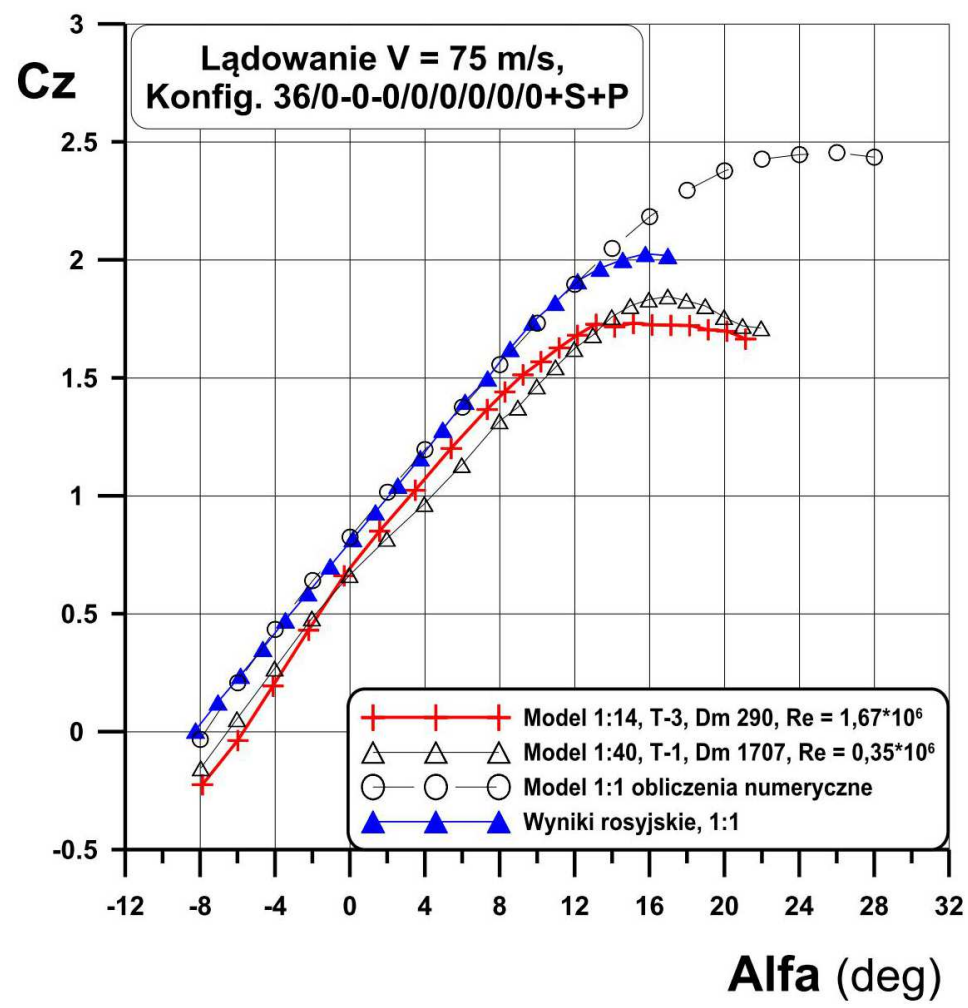

Rys. 7. Porównanie zależności $C z=(\alpha)$ uzyskanych w tunelach T-3 i T-1 oraz z wynikami obliczeń numerycznych i rosyjskich badań w locie dla konfiguracji do lądowania 


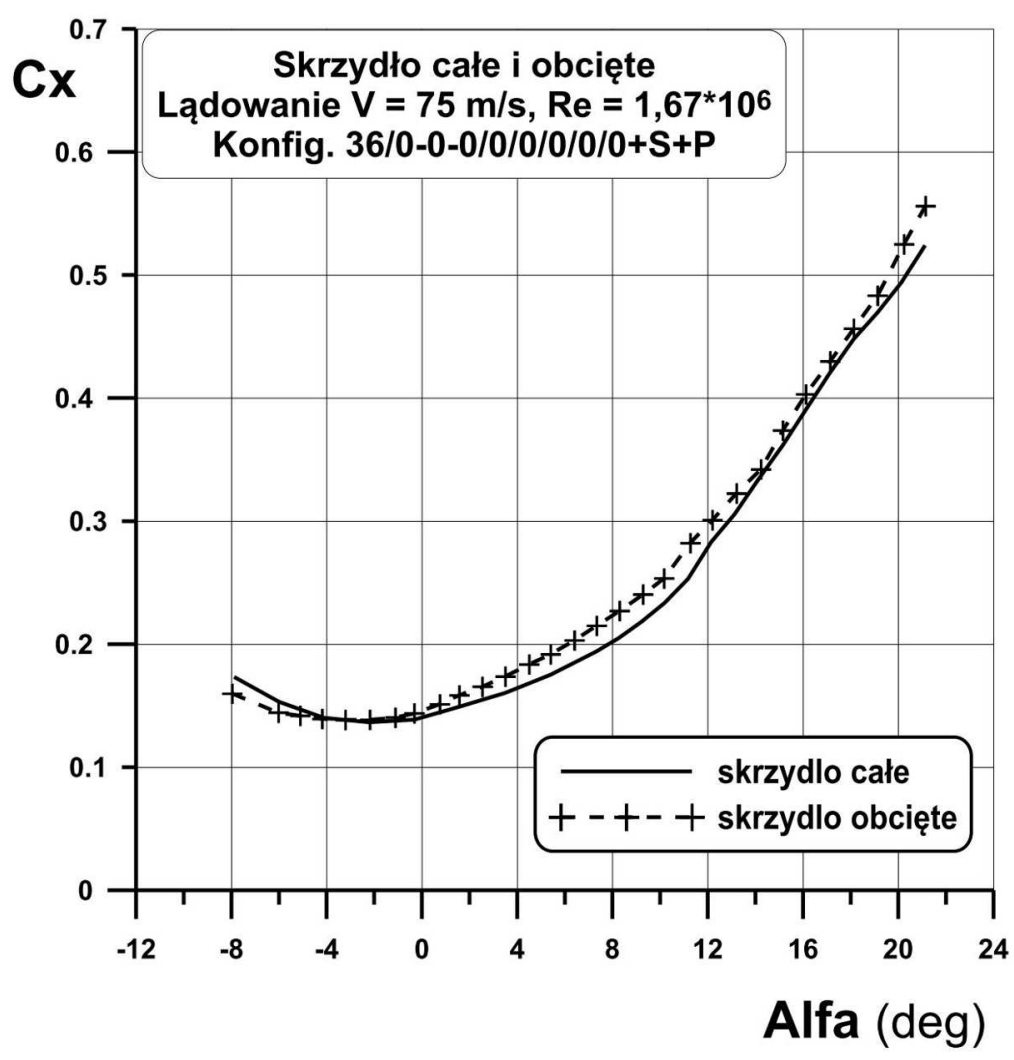

Rys. 8. Wpływ utraty końcówki lewego skrzydła na współczynnik siły oporu

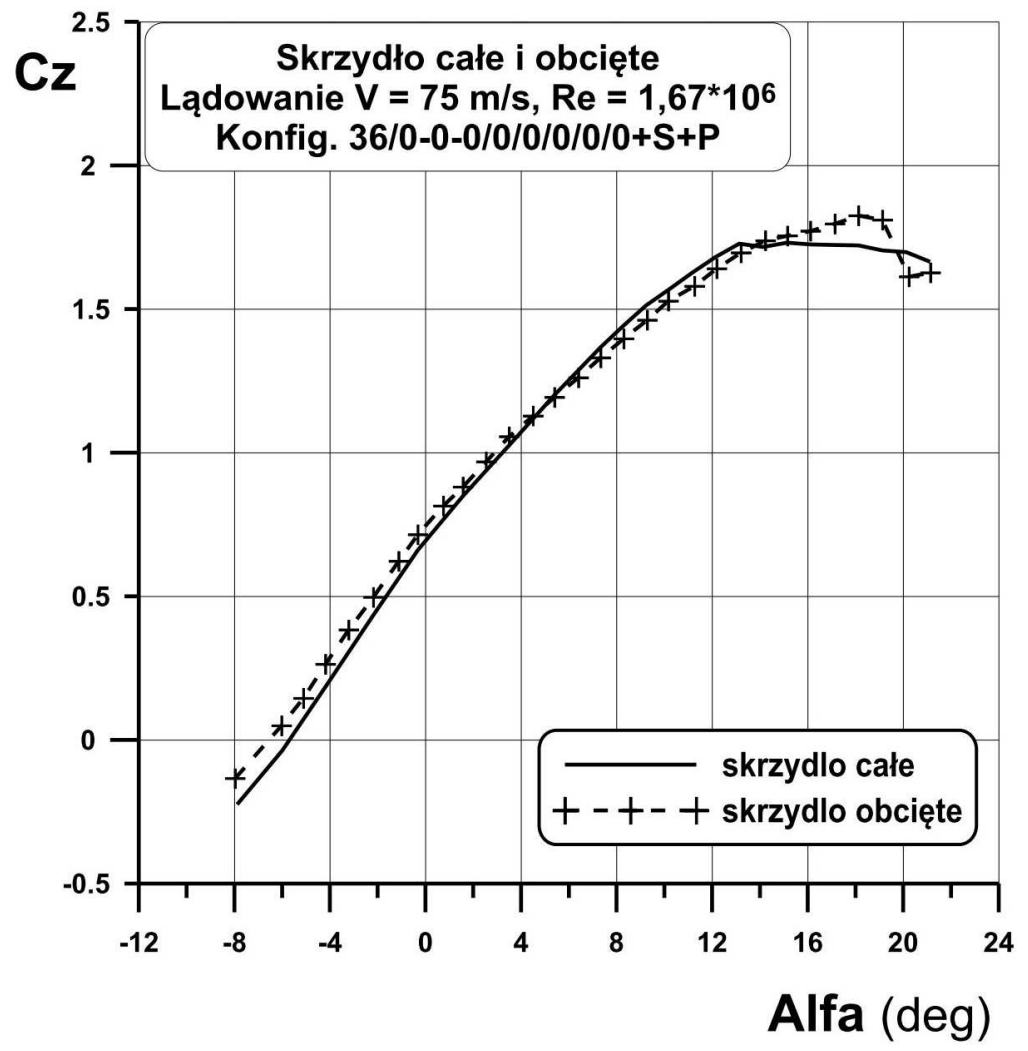

Rys. 9. Wpływ utraty końcówki lewego skrzydła na współczynnik siły nośnej 


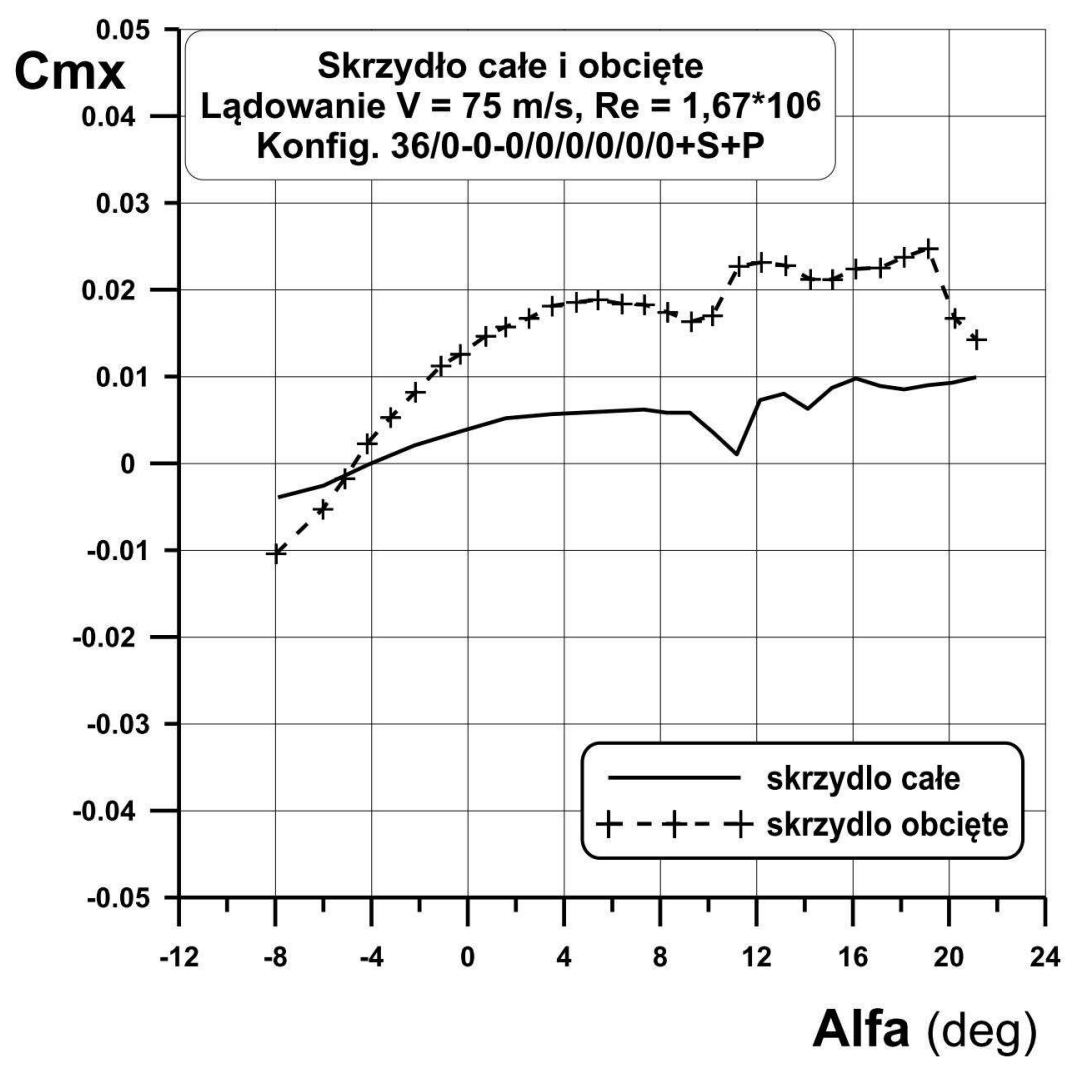

Rys. 10. Wpływ utraty końcówki lewego skrzydła na współczynnik momentu przechylającego

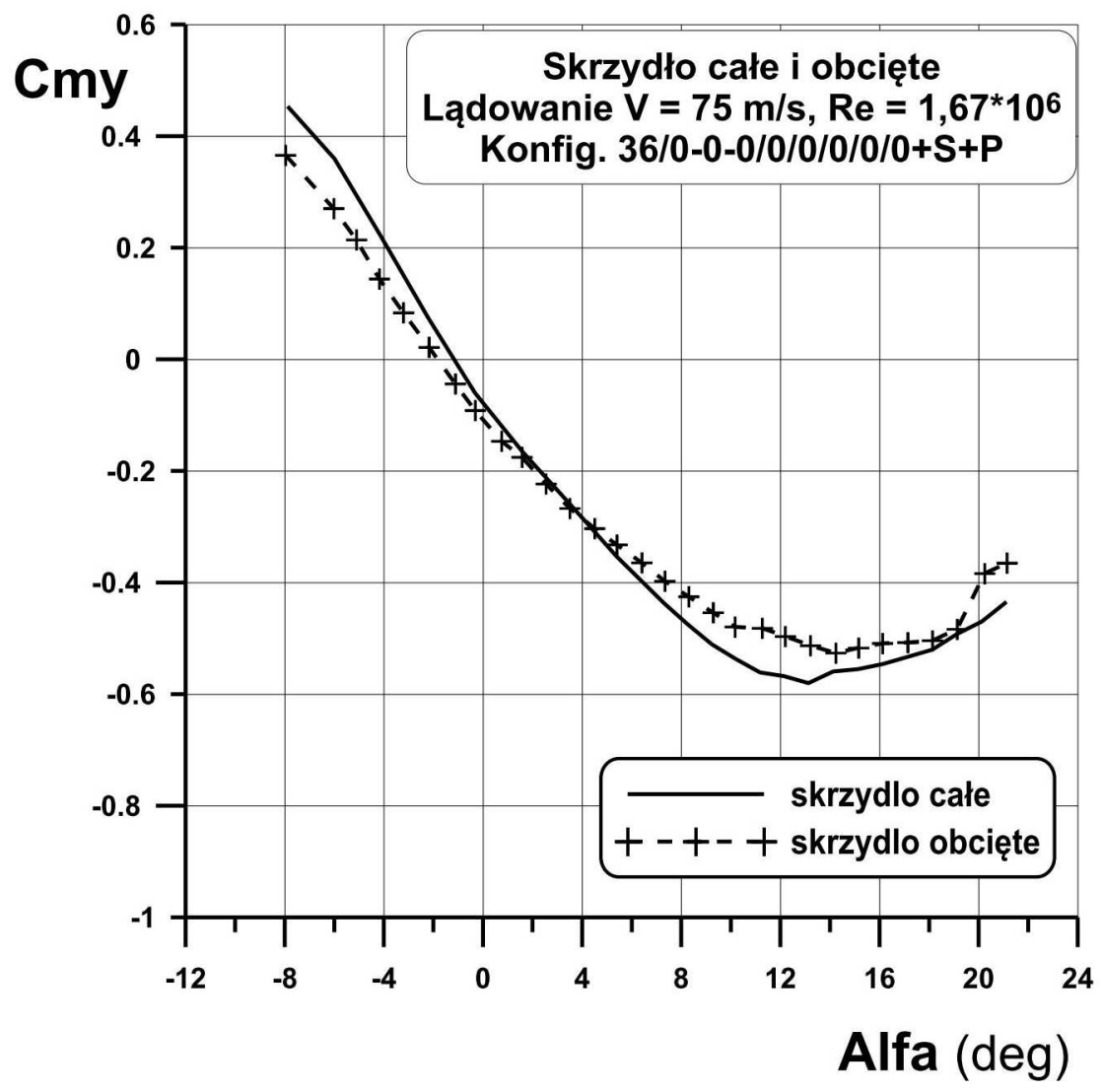

Rys. 11. Wpływ utraty końcówki lewego skrzydła na współczynnik momentu pochylającego 


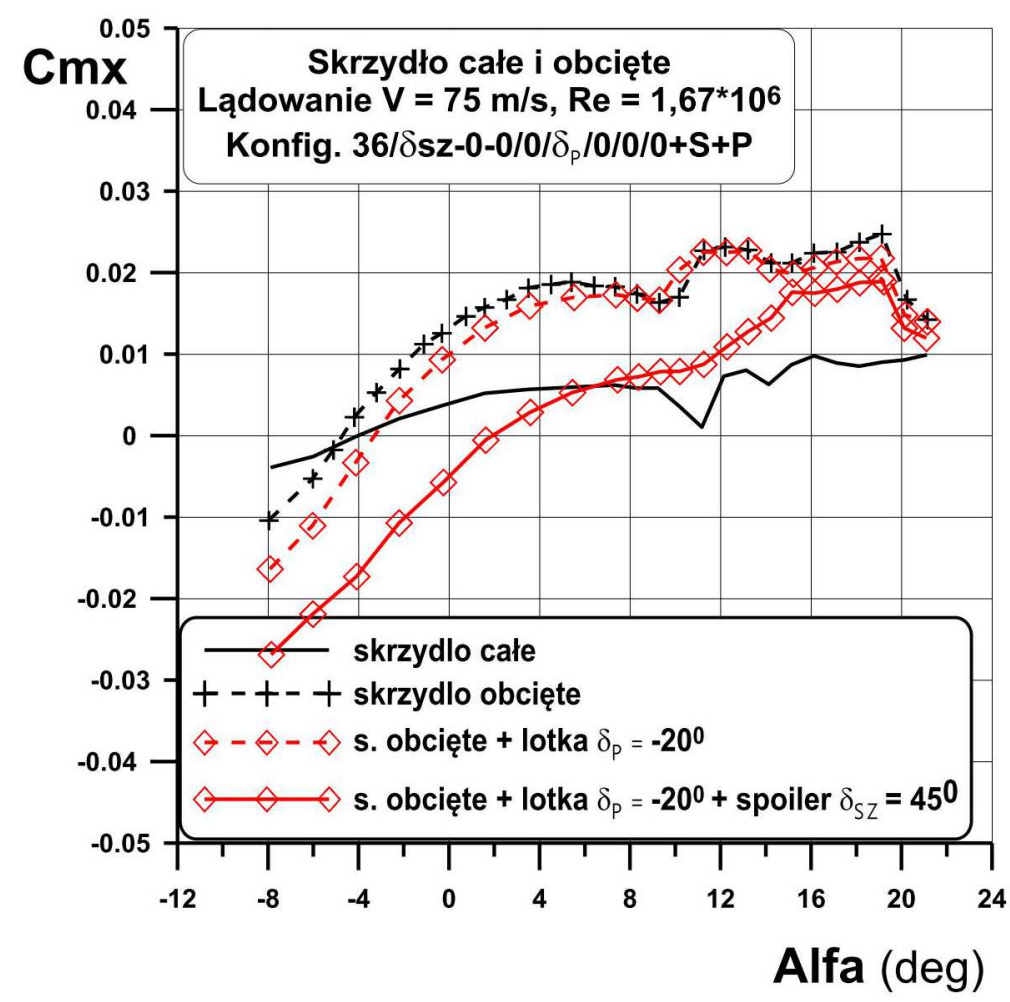

Rys. 12. Wpływ wychylenia prawej lotki oraz prawego zewnętrznego spoilera na współczynnik momentu przechylającego

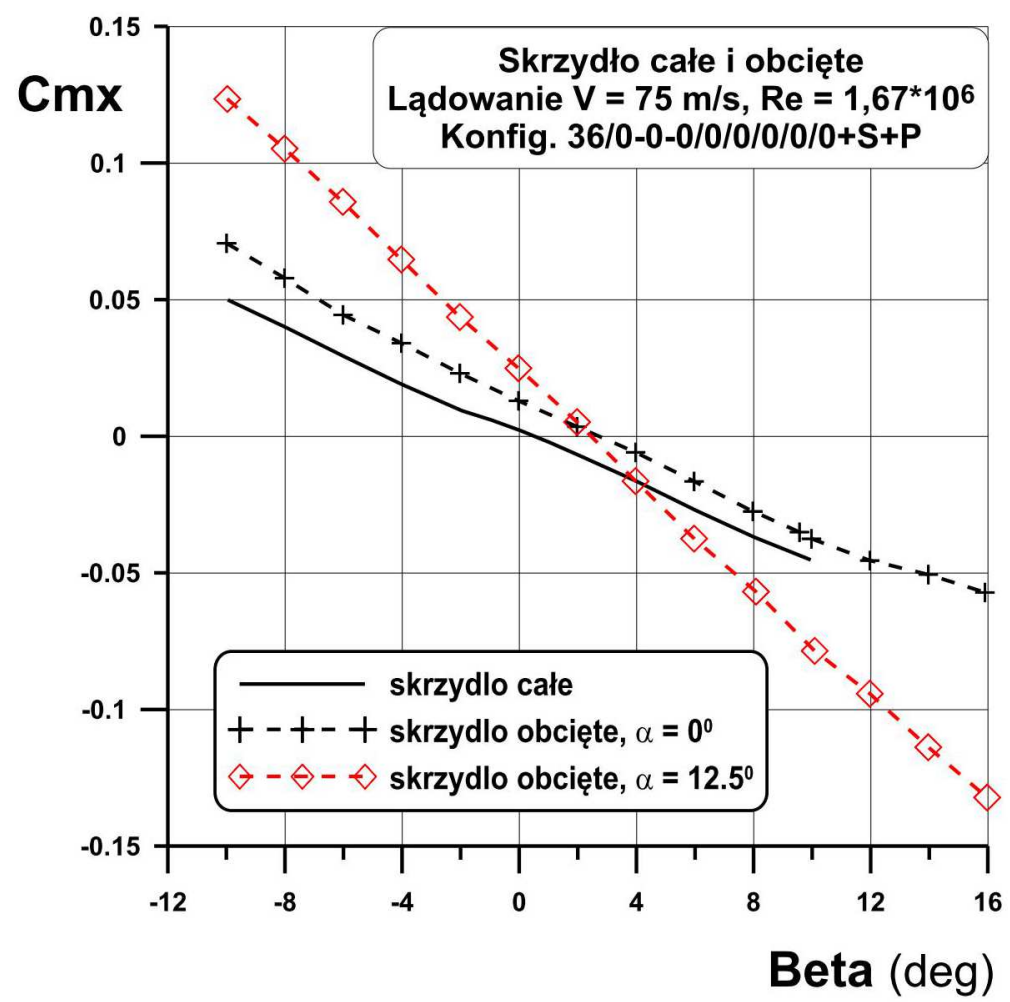

Rys. 13. Wpływ kąta ślizgu na współczynnik momentu przechylającego 


\section{Wnioski}

W artykule przedstawiono wyniki eksperymentalnych badań modelu samolotu Tu-154M (w skali 1:40) przeprowadzonych $\mathrm{w}$ tunelu małych prędkości T-1 Instytutu Lotnictwa. Badania miały na celu określenie wpływu uszkodzenia skrzydła samolotu Tu-154M na aerodynamikę tego samolotu. Uszkodzenie dotyczyło utraty jednej trzeciej końcówki lewego skrzydła samolotu. Badania eksperymentalne przeprowadzono przy prędkości przepływu niezakłóconego $V_{\infty}=20 \div 40 \mathrm{~m} / \mathrm{s}$.

Analiza wyników badań prowadzi do następujących wniosków:

- zmiana prędkości przepływu niezakłóconego w zakresie $V_{\infty}=20 \div 40 \mathrm{~m} / \mathrm{s}$ nie ma wpływu na charakterystyki aerodynamiczne badanego modelu samolotu,

- utrata jednej trzeciej lewego skrzydła samolotu Tu-154M zasadniczo nie powoduje dramatycznych zmian właściwości aerodynamicznych samolotu, z wyjątkiem momentu przechylającego,

- badania wykazały, że uszkodzenie skrzydła samolotu nie wpłynęło zasadniczo na zmianę oporu całkowitego samolotu, spowodowało natomiast nieduży spadek siły nośnej, o mniej niż $5 \%$,

- utrata jednej trzeciej lewego skrzydła samolotu Tu-154M powoduje pojawienie się momentu przechylającego o istotnej wartości, zależnej od kata natarcia samolotu (np. dla $\alpha=15^{\circ}$ otrzymujemy $\Delta C m x \sim 0.04)$,

- badania wykazały, że pomimo pojawienia się momentu przechylającego o istotnej wartości, będącej skutkiem utraty jednej trzeciej lewego skrzydła samolotu, istnieją potencjalne możliwości zrównoważenia lotu samolotu. Tę równowage można by było uzyskać poprzez równoczesne wychylenie lotki oraz spoilera na prawym skrzydle samolotu lub też poprzez wprowadzenie samolotu w ślizg na prawe skrzydło.

\section{Bibliografia}

1. Aviation Safety Network Database, http://aviation-safety.net/database/record.php?id=19650628-0

2. Grant R., Ascendent eagle, Air Force Magazine, July 2013

3. LeOne D., How an Israeli F-15 Eagle Managed to Land with One Wing, 2014, https://theaviationist.com/2014/09/15/f-15-lands-with-one-wing

4. Dewitte L., F-16 Crashes Following Midair Collision in Kansas, F-16.net, 2014, http://www.f-16.net/f-16-news-article4901.htm

5. Shat G.H., Aerodynamic effects and modeling of damage to transport aircraft, Procedings AIAA Atmospheric Flight Mechanics Conference and Exhibit, AIAA 2008-5203, 2008

6. Shaн G.H., Flight dynamics modeling and simulation of a damaged transport aircraft, AIAA Modeling and Simulation Technologies Conference, AIAA 2012-4632, 2012

7. Wiśniowski W., Tunele aerodynamiczne w Polsce na tle tuneli światowych, Biblioteka Naukowa Instytutu Lotnictwa, 42, 2016

8. Olejnik A., Kachel S., Kiszkowiak Ł., Mikoøajczyk M., Radomski M., Analiza wyników badań prowadzonych w WAT na rzecz wyjaśnienia przyczyn katastrofy smoleńskiej, Wydawnictwo Wojskowej Akademii Technicznej, 2017

9. Krzysiak A., Wind tunnel tests of the Tu-154M aircraft aerodynamic characteristics, Journal of Kones, 3, 26, 2019

10. Bechtir W., Rżewskij W., Cipienko W., Prakticzeskaja aerodinamika samoleta Tu-154M, Moskwa, Wozdusznyj Transport, 1997 


\section{Experimental studies of the effect of wingtip loss on the lateral balance of Tu-154M aircraft}

This paper presents results of experimental wind tunnel tests of Tu-154 M aircraft model at the 1:14 scale. The model was mostly made in composite technology with metal fastening elements and smaller elements printed in 3D technology. The model of Tu-154M aircraft was designed and manufactured by the Military University of Technology based on the exact geometry of the aircraft obtained by scanning the real-size object. The tests included measurements of basic aerodynamic characteristics in a number of configurations, including landing configuration (slots and landing gear extended, flaps extended to $36^{\circ}$ ) with no damage to the wing, and in the same configuration, but with the left wingtip cut off (approximately, one third of its span). The performed tests allowed one to determine the impact of the wingtip loss on the aircraft lateral balance. The tests of the model of $\mathrm{Tu}-154 \mathrm{M}$ aircraft were carried out in the T-3 low-speed wind tunnel (with a $5 \mathrm{~m}$ diameter test section) at the Institute of Aviation, for an undisturbed flow velocity of $V=75 \mathrm{~m} / \mathrm{s}$, which corresponded to the Reynolds number (related to the wing mean aerodynamic chord) $\mathrm{Re}=1.67 \cdot 10^{6}$. The measurements of aerodynamic characteristics were carried out both at a variable angle of attack, i.e. for $-8^{\circ} \leqslant \alpha \leqslant 22^{\circ}$ at the sideslip angle $\beta=0^{\circ}$, and at a variable sideslip angles, i.e. for $10^{\circ} \leqslant \beta \leqslant 16^{\circ}$ at the angle of attack $\alpha=0^{\circ}, 10^{\circ}, 12.5^{\circ}$.

The research discussed in this paper was commissioned by a Subcommittee for Re-Examination of Air Accident, operating at the Ministry of National Defense. 